\title{
MECHANISM OF THE ELECTROCOAGULATION PROCESS AND ITS APPLICATION FOR TREATMENT OF WASTEWATER: A REVIEW
}

Tijana Jovanović* Nena Velinov, Milica Petrović, Slobodan Najdanović, Danijela Bojić, Miljana Radović, Aleksandar Bojić

University of Niš, Faculty of Sciences and Mathematics, Department of Chemistry, Niš, Serbia
(REVIEW PAPER)

UDC 66.087.5:628.387

DOI $10.5937 /$ savteh2101063J

Treatment of wastewater, especially of industrial origin, is a major challenge. Although wastewater treatment methods have already been established, active efforts are being made to develop more efficient and economical methods. In recent years, the attention has been focused on electrochemical methods, most of which are focused on electrocoagulation. This paper gives a detailed description of the mechanism of the electrocoagulation process, as well as the application of this method in wastewater treatment of different origins.

Keywords: effluents; electrochemical methods; electrocoagulation; pollutants; wastewater; wastewater treatment;

\section{Introduction}

Due to the rapid urbanization and industrialization, as well as world population growth, quality of water and the available amount of clean water are becoming a crucial problem, especially for third world countries. Rivers, canals, estuaries, and other water surfaces are constantly being polluted due to the discharge of wastewaters from various industries, including other anthropogenic activities and natural processes. Wastewater can not only cause irreversible damage to the ecosystem but also contribute to the reduction of available clean water. Consequently, it is exceptionally important to treat wastewaters before their discharge into the environment to achieve the reduction of environmental pollution, as well as to consider the possibility of their reuse [1-5]. Although wastewater treatment technology is already an established science, the development of technologies that use a minimum amount of chemicals, a minimum of energy and that are more economical is still necessary. Additionally, with the wastewater discharge standards getting stricter, research is aimed at developing alternative wastewater treatment procedures that are more efficient than conventional treatment processes such as ion exchange, aerobic and anaerobic treatment, advanced oxidation processes, electrochemical techniques (electrocoagulation, electrooxidation and electroflotation), etc.

Out of the mentioned treatments, electrocoagulation process has been proposed for water purification and removal of pollutants of different nature [6]. Electrocoagulation (EC) process is used to treat wastewaters from various industries and is effective in removing dissolved substances and suspended matter. Wastewater treatment by electrochemical coagulation was used in the 20th century but without much success, due to the high consumption of electricity and cost of the process. Great effort has been invested in defining the main operating parameters for optimization of this process, in order to minimize electricity consumption and maximize the flow rate of effluents [7]. The aim of this paper is to present the fundamentals on which electrocoagulation is based, its advantages and disadvantages as well as the wide range of application.

Table 1. Advantages and disadvantages of the EC process

\begin{tabular}{ll}
\hline \multicolumn{1}{c}{ Advantages } & \multicolumn{1}{c}{ Disadvantages } \\
\hline Simple equipment and low-maintenance & Electrodes must be replaced regularly \\
Low cost treatment & Conductivity of treated water must be high \\
Treated water is colorless, odorless and clear & Passivation of electrodes decreases the efficiency of the process \\
Additional chemicals are not required & \\
Low sludge producing process & \\
The produced gas bubbles perform flotation & \\
\hline
\end{tabular}

\section{Electrocoagulation process}

EC is a process in which coagulants and metal hydroxides are electrochemically generated, in situ, which causes the destabilization and aggregation of contaminants (which are either suspended, dissolved, or dis- persed). Compared to the conventional coagulation process, the EC process is more effective in removing contaminants without the use of additional chemical reagents [8]. Furthermore, in this process, a smaller amount of sludge is generated, so the cost of the sludge removal process is reduced. Advantages and disadvantages of

\footnotetext{
*Author address: Jovanović Tijana, University of Niš, Faculty of Sciences and Mathematics, Department of Chemistry,

Višegradska 33, 18000 Niš, Serbia

E-mail: tijana.jovanovic@pmf.edu.rs

The manuscript received: November, 24, 2020

Paper accepted: January, 28, 2021.
} 
the EC process are listed in Table 1. In practice, the EC process is usually accompanied by electroflotation (EF) process. EF is a process in which pollutants are separated on the surface of water by electrochemically generated hydrogen and oxygen gas. This combined system is commonly referred to as electrocoagulation-flotation (ECF) process [9] .

\section{Mechanism of EC}

The reaction mechanism of $\mathrm{EC}$ is shown in Figure 1. The EC unit consists of an electrochemical cell in which the electrodes are located and connected to an external current supply. The generation of coagulants, i.e. metal ions, is performed in situ, by dissolving the anode material (equation 1):

$M_{(s)} \rightleftharpoons M_{(a q)}^{n+}+n e$

The reaction that takes place on the cathode is the reduction of water, which results in the generation of hydrogen gas and hydroxyl ions (equation 2) [10,11]:

$4 \mathrm{H}_{2} \mathrm{O}+4 e^{-} \rightleftharpoons 2 \mathrm{H}_{2(g)}+4 \mathrm{HO}_{(a q)}^{-}$

The reaction that takes place on the anode is the oxidation of water (equation 3):

$\mathrm{H}_{2} \mathrm{O} \rightleftharpoons 4 \mathrm{H}_{(a q)}^{+}+\mathrm{O}_{2(g)}+4 e^{-}$

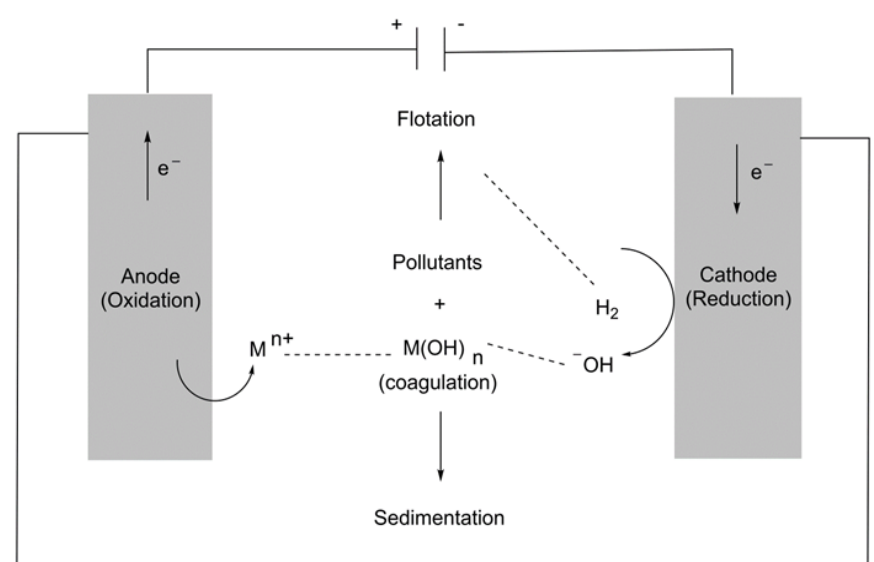

Figure 1. Mechanism of pollutant removal by EC process

The EC process usually involves the following steps: 1. sacrificing the anode material under the influence of an electric current, which leads to the generation of metal cations; 2 . the generation of hydroxyl ions on the cathode; 3. formation of metal hydroxides with good adsorption properties that bind pollutants; 4. oxidation of pollutants to less toxic products; 5 . neutralization of charged pollutants with metal ions; 6. aggregation of neutralized pollutants and their adsorption; 7 . flotation using the gases produced in the system $[6,12,13]$. Metal ions formed by dissolving the anode material react with hydroxyl ions generated at the cathode, forming hydrox- ides that are good adsorbents. Iron and aluminum are most often used to produce anodes, due to the formation of polyvalent ions and various hydrolysis products, which depend on the $\mathrm{pH}$ of the solution as well as the possibility of forming polynuclear complexes [14-16]. Therefore, the $\mathrm{pH}$ of the solution has a great influence on the efficiency of EC. The hydrolysis reaction can be represented by equation (4):

$\mathrm{M}^{3+} \rightarrow \mathrm{Me}(\mathrm{OH})^{2+} \rightarrow \mathrm{Me}(\mathrm{OH})_{2}^{+} \rightarrow \mathrm{Me}(\mathrm{OH})_{3} \rightarrow \mathrm{Me}(\mathrm{OH})_{4}^{-}$

As the $\mathrm{pH}$ of the solution increases, the reaction continues, giving other products. Iron will be present in the form of ferric ions $\left(\mathrm{Fe}^{3+}\right)$ at $\mathrm{pH}<3$, at $\mathrm{pH}$ from 3 to 4 it will be in the form of $\mathrm{Fe}(\mathrm{OH})^{2+}$, from 4 to 6 in the form of $\mathrm{Fe}(\mathrm{OH})_{2}{ }^{+}$, from 6 to 9,5 in the form of $\mathrm{Fe}(\mathrm{OH})_{3}$, and at $\mathrm{pH}$ values greater than 9.5 , it will be present in the form of $\mathrm{Fe}(\mathrm{OH})_{4}^{-}$. Aluminum hydrolysis reactions in aqueous solutions give $\mathrm{Al}^{3+}, \mathrm{Al}(\mathrm{OH})^{2+}, \mathrm{Al}(\mathrm{OH})_{2}{ }^{+}$and $\mathrm{Al}(\mathrm{OH})_{3}$ as the dominant species in acidic, neutral and slightly alkaline solutions, while $\mathrm{Al}(\mathrm{OH})_{4}^{-}$will be present in alkaline solutions [17]. Insoluble forms, $\mathrm{Fe}(\mathrm{OH})_{3}$ and $\mathrm{Al}(\mathrm{OH})_{3}$ remain in the solution and destabilize contaminants by electrostatic attraction forces. Destabilization of contaminants takes place through two mechanisms: 1. cation hydrolysis products neutralize negatively charged colloidal particles; 2. removal of pollutants in the form of an amorphous hydroxide [10].

Effects of operational parameters on the EC process

To obtain the maximum possible efficiency of the EC process, it is necessary to understand the influence of operational parameters on the EC process.

\section{Current density}

One of the most important operating parameters of the EC process is the current density, i.e. the amount of electric current that flows through the unit area of the electrode. The number of ions that will be generated by anode dissolution will be directly proportional to the applied current density. The relationship between current density and the number of generated ions can be explained by Faraday's law (equation 5):

$w=j \cdot t \cdot \frac{m}{n} \cdot F$

where $w$ is the amount of electrode material that dissolves $\left(\mathrm{g} \mathrm{cm}^{-2}\right), t$ is the duration of electrolysis (s), $j$ is the applied current density $\left(\mathrm{mA} \mathrm{cm}^{-2}\right), m$ is the relative molar mass of the material from which the electrode was made $\left(\mathrm{g} \mathrm{mol}^{-1}\right), n$ is the number of exchanged electrons in the reaction and $\mathrm{F}$ is Faraday's constant (96 $500 \mathrm{C}$ $\left.\mathrm{mol}^{-1}\right)$ [10].

Even though the amount of generated ions corresponds to the applied current, using larger operating current densities enables secondary reactions, which reduces current efficiency [6]. Using excessively large current densities also increases the possibility of wasting 
electrical energy, which is manifested by heating of the treated solution. The recommended value of operating current density varies widely for different types of treated water. Selection of the operating current density should be in accordance with other operating parameters, such as solution flow rate, solution $\mathrm{pH}$ and temperature to ensure high process efficiency. The current density and the anions present in the water influence the current efficiency. The current efficiency for the aluminum electrode can be from 120 to $40 \%$, while for the iron electrodes it is about $100 \%$ [18]. Current efficiency greater than $100 \%$ is due to the effect of pitting corrosion, particularly in the presence of chloride anions. The quality of the treated wastewater will depend on the amount of generated ions (mg) or the charge loading. The values of $\mathrm{Al}^{3+}$ ions $(\mathrm{mg})$ required for removing typical pollutants that are often present in wastewater are given in Table 2. The existence of required critical charge loading should be emphasized and when it reaches the critical value, the quality of wastewater does not show significant improvement with the further current increase [6].

Table 2. Required values of aluminum and power consumption for removing pollutants from water [1]

\begin{tabular}{cccccc}
\hline Pollutant & Unit quantity & \multicolumn{2}{c}{ Preliminary treatment } & \multicolumn{2}{c}{ Treatment } \\
& & $\mathrm{Al}^{3+}(\mathrm{mg})$ & $\mathrm{E}\left(\mathrm{W} \mathrm{hm}^{-3}\right)$ & $\mathrm{Al}^{3+}(\mathrm{mg})$ & $\mathrm{E}\left(\mathrm{W} \mathrm{hm}^{-3}\right)$ \\
\hline Turbidity & $1 \mathrm{mg}$ & $0.04-0.06$ & $5-10$ & $0.15-0.2$ & $20-40$ \\
Color & $1 \mathrm{unit}$ & $0.04-0.1$ & $10-40$ & $0.1-0.2$ & $40-80$ \\
Silicates & $1 \mathrm{mg} \mathrm{SiO}_{2}$ & $0.2-0.3$ & $20-60$ & $1-2$ & $100-200$ \\
Iron & $1 \mathrm{mg} \mathrm{Fe}$ & $0.3-0.4$ & $30-80$ & $1-1.5$ & $100-200$ \\
Oxygen & $1 \mathrm{mg} \mathrm{O}_{2}$ & $0.5-1$ & $40-200$ & $2-5$ & $80-800$ \\
Algae & 1000 & $0.006-0.025$ & $5-10$ & $0.02-0.03$ & $10-20$ \\
Bacteria & 1000 & $0.01-0.04$ & $5-20$ & $0.15-0.2$ & $40-80$ \\
\hline
\end{tabular}

\section{Electrolysis time}

Electrolysis time has a significant effect on the efficiency of pollutant removal by the EC process. It defines the amount of coagulant being generated, as well as the cost of the process [19]. By increasing the electrolysis time, the efficiency of pollutant removal at constant current density increases due to the increment of the amount of formed coagulant to a certain value. Increasing the electrolysis time above the optimal value does not further affect the efficiency of the process [18]. It should be noted that an increase in electrolysis time affects the cost of the process due to the higher consumption of energy and electrode material.

Inter-electrode distance

The distance between the electrodes is also an important factor in the EC process - the electrostatic field depends on the distance between the anode and cathode [19]. Maximum efficiency of pollutant removal can be provided with the optimal inter-electrode distance, while minimum distance between the electrodes provides low efficiency of pollutant removal. The greater the distance between the cathode and the anode, the slower the generated ions will move. Due to the slower movement, the generated ions have more time to form flocs and coagulate pollutants. Increasing the distance above the optimal value reduces the dissolution of the anode material and increases the distance that the ions need to travel to form flocs, which reduces the efficiency of the process.

The efficiency of the EC process will also depend on the conductivity of the treated water. The electrical conductivity is directly proportional to the distance between the electrodes. With the increase of the distance between the cathode and the anode the resistance of the cell also increases, which can be seen from equation (6) [20]:

$R=\frac{d}{k A}$

where $d$ is the inter-electrode distance $(\mathrm{cm}), R$ is the resistance of the cell $(\Omega), \mathrm{k}$ is the specific conductivity $\left(\mathrm{S} \mathrm{cm}^{-1}\right)$ and $A$ is the electrode surface area $\left(\mathrm{cm}^{2}\right)$. The current will increase with the decrease in the resistance, and with the current increase, the number of ions generated will also increase, as well as the efficiency of the EC process [10].

\section{Electrode arrangement}

The electrode material and the arrangement of electrodes are of great importance for the cost of the EC process. The material from which the electrode is made defines the type of electrochemical reaction that will take place in the EC system. The most commonly used anode materials are aluminum and iron, while inert materials such as steel, stainless steel or platinum are usually used as cathode materials [21]. The EC system may consist of one or more pairs of electrodes, and the electrode connection mode can be monopolar parallel (MP$\mathrm{P})$, bipolar parallel (BP-P) or monopolar serial (MP-S). In the MP-P mode of connection (Figure 2a), the anodes and cathodes are connected in parallel. This connection method requires a lower potential difference compared to serial connection. In the BP-P mode of connection (Figure 2b), the sacrificial electrodes are placed between the parallel electrodes and are not connected to the power supply. MP-P electrodes are connected to the power supply, with no interconnection between the sacrificial electrodes. As current passes through the monopolar 
electrodes, the neutral sides of the sacrificial anodes will have opposite charges compared to the adjacent electrode side. This way of connecting is quite simple, so maintaining such a system is not demanding.

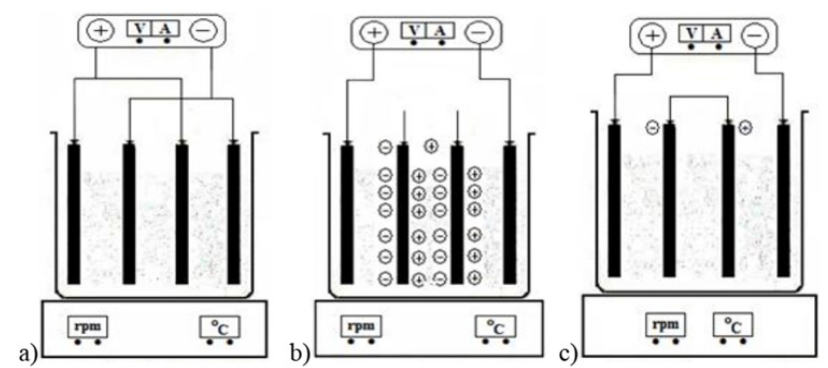

Figure 2. Different modes of electrode connection: a) monopolar parallel (MP-P); b) bipolar parallel (BP-P); c) monopolar series (MP-S) [21]

In the MP-S mode of connection (Figure 2c), all sacrificial electrode pairs are interconnected. This means that the cell voltage sums up, which is why a greater potential difference is needed [21,22].

\section{Presence of sodium chloride}

Sodium chloride is usually added to increase the conductivity of the treated wastewater [6]. In addition to contributing to the conductivity of the solution, it has been found that chloride anions can reduce the harmful effects of other anions present in water, such as bicarbonate $\left(\mathrm{HCO}_{3}{ }^{-}\right)$and sulfate $\left(\mathrm{SO}_{4}{ }^{2-}\right)$ anions. The presence of carbonate or sulfate anions can lead to the deposition of $\mathrm{Ca}^{2+}$ or $\mathrm{Mg}^{2+}$ ions, which would result in the formation of an insulating layer on the electrode surface. This non-conductive layer would significantly increase the potential between the electrodes, which would reduce the current efficiency. Therefore, it is recommended that the content of chloride anions be up to $20 \%$ to ensure the normal course of the electrocoagulation process. Also, due to the increase in conductivity there is a decrease in power consumption [23].

\section{Solution $\mathrm{pH}$}

The influence of the $\mathrm{pH}$ value of the treated water on the efficiency of the EC process is reflected in the current efficiency and the solubility of metal hydroxides. The $\mathrm{pH}$ will also affect the release of chlorine gas if chlorides are present in the treated water [11]. It was found that the current efficiency, while using aluminum electrodes, is the highest in acidic and alkaline media. The current efficiency will depend on the nature of the pollutants in neutral media. However, the power consumption will be higher at neutral $\mathrm{pH}$ values due to changes in conductivity [9]. When the conductivity of the treated water is high, the $\mathrm{pH}$ will not significantly affect the efficiency of the process. One of the advantages of the EC process is an increase in the $\mathrm{pH}$ value for acidic effluents, while it decreases for alkaline ones. The increase in $\mathrm{pH}$ of acidic effluents is attributed to the evolution of hydrogen gas at the cathode [24]. In addition to the evolution of hydrogen, the process of oxygen evolution takes place, as well as the formation of aluminum hydroxide next to the anode (releasing $\mathrm{H}^{+}$ions), which would lead to a decrease in the $\mathrm{pH}$. When chloride anions are present in the solution, chemical reactions given by equations (7), (8) and (9) occur:

$2 \mathrm{Cl}^{-} \rightleftharpoons \mathrm{Cl}_{2}+2 \mathrm{e}^{-}$

$\mathrm{Cl}_{2}+\mathrm{H}_{2} \mathrm{O} \rightleftharpoons \mathrm{HOCl}+\mathrm{Cl}^{-}+\mathrm{H}^{+}$

$\mathrm{HOCl} \rightleftharpoons \mathrm{OCl}^{-}+\mathrm{H}^{+}$

This shows that the increase of $\mathrm{pH}$ caused by the reduction of $\mathrm{H}^{+}$ions is mostly compensated by the formation of $\mathrm{H}+$ ions as shown in equations (7), (8) and (9). The increase in the $\mathrm{pH}$ of acidic effluents is a consequence of the formation of $\mathrm{Al}^{3+}$ precipitates due to the presence of other anions, as well as the precipitation of aluminum hydroxide [8].

On the other hand, the decrease in the $\mathrm{pH}$ of alkaline effluents is a result of $\mathrm{Al}(\mathrm{OH})_{4}{ }^{-}$formation as shown by equation (10):

$\mathrm{Al}(\mathrm{OH})_{3}+\mathrm{HO}^{-} \rightarrow \mathrm{Al}(\mathrm{OH})_{4}$

It was found that when Fe electrodes are used, decolorization efficiency was better in alkaline effluents, as well as chemical oxygen demand (COD) removal [25].

\section{Solution temperature}

The effect of temperature on the efficiency of pollutant removal by the EC process is of great importance. Higher working temperatures could decrease the efficiency of the process, which would be a result of the decrease in metal hydroxide formation [6]. Lower working temperatures could also lead to a decrease in the efficiency of pollutant removal because it would slow down the electrode dissolution process. Working temperature, beyond the shadow of a doubt, affects the EC process by changing the rates of reactions that take place in the medium, solubility of metal hydroxide, the conductivity of treated water and the kinetics of colloidal particles and gas bubbles [9]. As the temperature increases up to $60^{\circ} \mathrm{C}$, the current efficiency also increases, after which it decreases [24]. The increase in current utilization with temperature is the result of the destruction of the aluminum oxide film on the electrode surface. Excessive operating temperatures result in the reduction of aluminum hydroxide pores, which allows the formation of more compact flocs that can be deposited on the electrode surface. Similarly, power consumption also increases with increasing temperature up to $35^{\circ} \mathrm{C}$ due to the increase of the conductivity and decrease of energy consumption [26]. The influence of temperature $\left(20-50^{\circ} \mathrm{C}\right)$ on the removal of phosphates from wastewater using aluminum electrodes showed that with the increase of temperature, the efficiency of pollut- 
ant removal also increases due to the faster transfer of aluminum ions from the anode to the bulk of the solution and an increase of the aluminum hydroxide formation rate. An increase in temperature above $50{ }^{\circ} \mathrm{C}$ leads to an increase in energy consumption, cost of the process, and a decrease in process efficiency [10].

\section{Initial pollutant concentration}

The initial concentration of the pollutant is also a parameter that significantly affects the efficiency of the EC process. According to the literature, the increase in the initial concentration of pollutants (while all other parameters are kept constant) affects the removal efficiency, because at fixed operating parameters the amount of the generated coagulant will also be constant, which will be insufficient for flocculation [27]. In this case, a longer electrolysis time is required to remove the residual concentration of pollutants. Higher initial concentrations not only reduce the efficiency of pollutant removal but also increase the resistance of the medium, and thus energy consumption [9].

\section{Power supply}

While passing through an electrochemical reactor, the current must overcome anode and cathode overpotentials, the equilibrium potential difference $E_{e q}(\mathrm{~V})$ and ohmic potential drop of the solution [28]. Anode overpotential includes the activation overpotential $\eta_{a, a}(\mathrm{~V})$ and the concentration overpotential $\eta_{a, c}(\mathrm{~V})$, and it might include the passive overpotential $\eta_{a, p}(\mathrm{~V})$ which is a direct consequence of the formation of a passive film on the electrode surface. Cathodic overpotential includes activation overpotential $\eta_{c, a}(\mathrm{~V})$ and concentration overpotential $\eta_{c, c}(\mathrm{~V})$. Thus, the cell voltage can be represented by the equation (11):

$U_{0}=E_{e q}+\eta_{a, a}+\eta_{a, c}+\eta_{a, p}+\left|\eta_{c, a}\right|+\left|\eta_{c, c}\right|+\frac{d}{k} j$

It is worth noting that the passive overpotential depends on the state of the electrode surface. For nonpassivated electrodes, passive overpotential will not be considered, so equation 11 can be written in the following form (equation 12):

$U_{0}=E+\frac{d}{k} i+K_{1} \ln j$

Cell voltage for systems with old, passivated electrodes will be presented by the equation (13):

$U_{0}=E+\frac{d}{k} i+K_{1} \ln j+\frac{K_{2} i^{n}}{k^{m}}$

In equations (12) and (13), both $K_{1}$ and $K_{2}$ are constants. Despite the equilibrium potential difference $E$ being related to the transport numbers of $\mathrm{Al}^{3+}$ and $\mathrm{OH}^{-}$, at high values of $\kappa$, which is the case for $E C$, it reaches a constant value. These two equations indicate the fact that the cell voltage does not depend on $\mathrm{pH}$ and does not change significantly with flow rate. For new aluminum electrodes, the value of $E$ is -0.76 , while $K_{1}$ is 0.2 . For passivated aluminum electrodes, $E=-0.43, K_{1}=0.2, K_{2}=$ 0.016 , while $m=0.47$ and $n=0.75$ [6]. With $U_{0}$ being defined, the total required voltage $U$ for the $E C$ process can be easily calculated. If the electrodes are connected in a monopolar (MP) mode, the total voltage will be the same as the voltage between the two electrodes (equation 14):

$U=U_{0}$

For the bipolar mode (BP) of connection, the total voltage will be the product of $U_{0}$ and the number of total cells in the system (equation 15):

$U=(N-1) U_{0}$

where $N$ is the number of electrodes present in the system, which is hardly ever greater than 8 , with the purpose being the maintenance of high current efficiency for each plate. Direct current power supply is usually applied, with the direction of current being changed at certain times to minimize passivation of electrode surface [28].

\section{Electrode material}

The choice of material from which the electrode will be made depends on the price of the material, its availability and its effect on the efficiency of the process [9]. Numerous electrode materials have been used in the EC process including aluminum, silver, arsenic, barium, calcium, cadmium, chromium, cesium, iron, magnesium, sodium, and silicon. Out of all the materials, aluminum and iron are most commonly used due to lower cost of these materials, their greater availability and good dissolution during the EC process [20].

The electrodes are usually made of aluminum or iron plates or waste material of these elements. If waste material, i.e. scraps are used, the electrode supports must be made of inert material. When applying waste material, special attention should be paid to possible deposits of sludge between scraps. It is also necessary to regularly rinse the electrodes, whether they are made of plates or waste. As the amounts of metal ions required to remove a certain amount of pollutants are defined, it is common to use iron electrodes for wastewater treatment, while aluminum electrodes are used to treat drinking water, because iron is cheaper. However, aluminum electrodes are also used for wastewater treatment, and in combination with iron electrodes due to the higher efficiency of aluminum ions as a coagulant [21]. When the water being treated contains considerable amounts of calcium and magnesium ions, the cathode material should be stainless steel.

Typical design of EC units

EC units can either be horizontal or vertical, which is dependent on the orientation of electrodes (Figure 3 ). To keep the system simple, the mode of connection of electrodes is bipolar. As for the inter-electrode water 
flow, it can be single and multiple channels (Figure 4). Multiple channel design is simpler, but the flow rates in each channel are small. When all else fails, increasing the flow rate by using the single-channel flow is sure to minimize the passivation of the electrode surface.

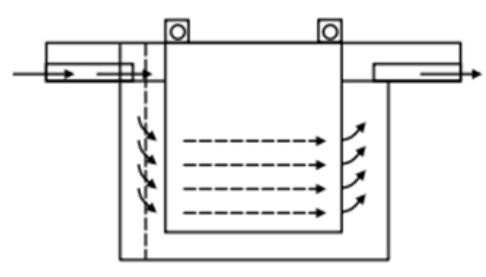

a)

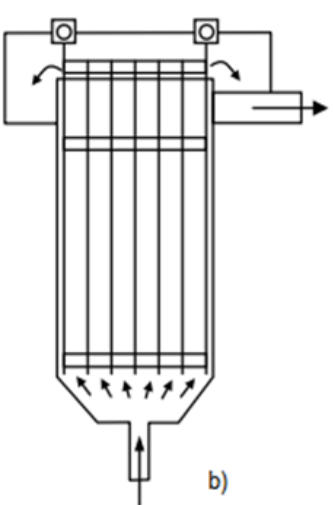

Figure 3. EC units with a) horizontal flow and b) vertical flow [6]

EC units with cylindrical electrodes are usually used for drinking water treatment (Figure 5). Cylindrical units can separate suspended solids (SS) from the treated water with great efficiency. To prevent clogging of the system, scraper blades are placed inside the cylinder. An alternative design to a cylindrical EC unit is shown in Figure 6. It is a device with a venturi in the center of the cylinder, through which water and coagulants pass, which ensures good mixing. EC units can be with a continuous or batch mode of operation, whereby automation is important for the batch mode of operation since it works with small amounts of water [6].

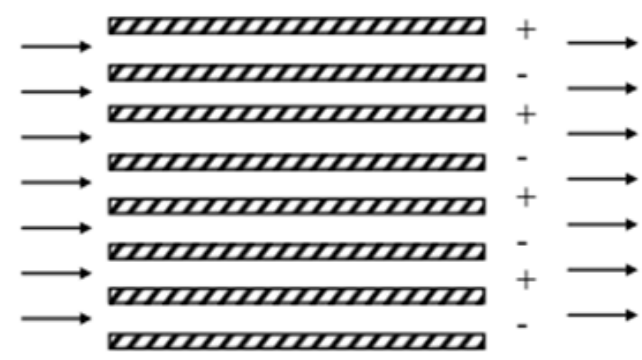

(a)

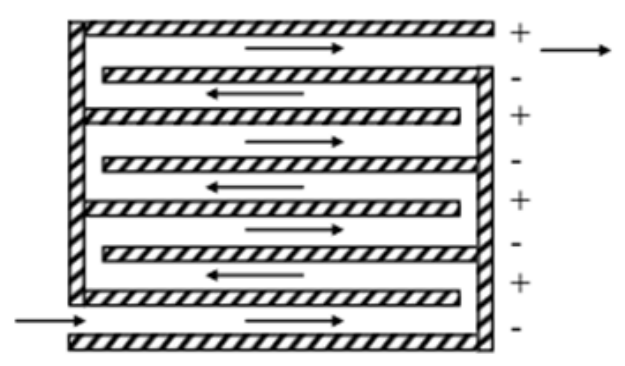

(b)

Figure 4. Mode of water flow; a) multiple channels; b) single channel [6]
It must be stressed that there is no empirical or systematic approach for EC unit design, so the performance comparison of different reactors is very difficult. The EC process must be followed by a sedimentation or flotation process to remove the sludge [25].

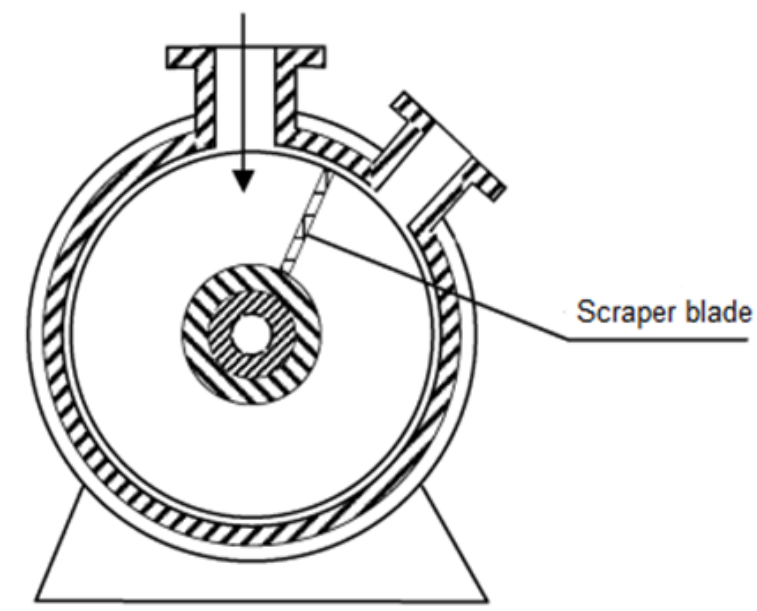

Figure 5. EC unit with cylindrical electrodes [6]

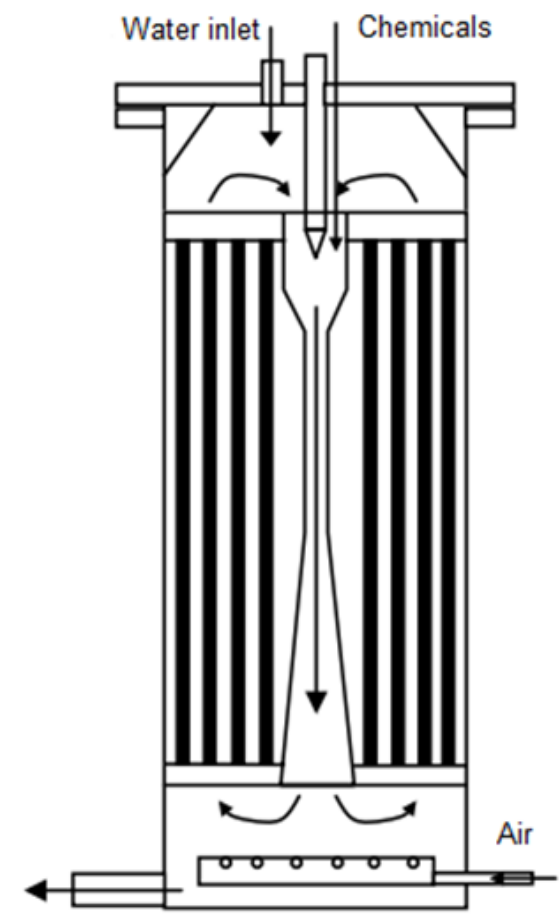

Figure 6. EC unit with a venturi [6]

Applications of the EC process

The EC process has been proven to be effective in the treatment of drinking water for smaller cities and medium-sized cities, and water needed for industrial processes in factories where it is not economical or not necessary to incorporate water treatment plants [6]. 
Table 3. A summary of recent EC studies and it's application on various wastewaters

\begin{tabular}{|c|c|c|c|c|c|c|}
\hline Wastewater type & Anode/Cathode & $\begin{array}{c}\text { Current } \\
\text { Density (mA } \\
\left.\mathrm{cm}^{-2}\right) \\
\end{array}$ & $\begin{array}{l}\text { Time } \\
(\min )\end{array}$ & $\mathrm{pH}$ & $\begin{array}{l}\text { Pollutant } \\
\text { removal \% }\end{array}$ & Reference \\
\hline $\begin{array}{l}\text { Tannery wastewater } \\
\text { containing organic and } \\
\text { inorganic pollutants }\end{array}$ & $\mathrm{Fe} / \mathrm{Fe}$ & 22.4 & 20 & $7-9$ & $\begin{array}{c}95 \% \mathrm{COD}^{2} \\
96 \% \mathrm{BOD}^{\mathrm{a}} \\
100 \% \mathrm{Cr} \\
96 \% \mathrm{TSS}^{\mathrm{b}} \\
62 \% \mathrm{TKN}^{\mathrm{c}} \\
50 \% \mathrm{TDS}^{\mathrm{d}} \\
99 \% \mathrm{O}^{\mathrm{e}} \\
\sim 98 \% \text { color }\end{array}$ & [33] \\
\hline Laundry wastewater & Graphite/Steel & 5.26 & 5 & 5.5 & $90 \%$ surfactant & [34] \\
\hline Textile wastewater & $\mathrm{Al} / \mathrm{Al}$ & 25 & 120 & 5 & $\begin{array}{c}18.6 \% \text { COD } \\
83.5 \% \text { turbidity } \\
98.36 \% \text { COD }\end{array}$ & [35] \\
\hline $\begin{array}{l}\text { Sulphide mineral } \\
\text { processing wastewater }\end{array}$ & $\mathrm{Al} / \mathrm{Al}$ & 90.01 & - & 6.5 & $\begin{array}{l}93.14 \% \mathrm{SO}_{4}^{2-} \\
94.86 \% \mathrm{Ca}^{2+}\end{array}$ & [36] \\
\hline $\begin{array}{l}\text { Black liquor wastewater } \\
\text { (from pulp and paper } \\
\text { industry) }\end{array}$ & $\mathrm{Al} / \mathrm{Fe}$ & 140 & 50 & $5-7$ & $\begin{array}{c}98 \% \text { COD } \\
92 \% \text { polyphenols } \\
99 \% \text { color }\end{array}$ & {$[37]$} \\
\hline $\begin{array}{l}\text { Highly complex industrial } \\
\text { wastewater (a mixture of }\end{array}$ & & & & & $\begin{array}{l}69 \% \text { COD } \\
71 \% \text { BOD }\end{array}$ & \\
\hline $\begin{array}{l}\text { wastewaters of } 144 \\
\text { different factories) }\end{array}$ & $\mathrm{Al} / / \mathrm{Fe}$ & 45.45 & 60 & 8 & $\begin{array}{l}80 \% \text { turbidity } \\
83 \% \text { color }\end{array}$ & [20] \\
\hline $\begin{array}{l}\text { Metal plating } \\
\text { wastewater }\end{array}$ & $\mathrm{Fe} / \mathrm{Al}$ & 100 & 20 & $7-9$ & $\begin{array}{l}100 \% \mathrm{Ni} \\
100 \% \mathrm{Cu} \\
100 \% \mathrm{Cr}\end{array}$ & [38] \\
\hline Municipal wastewater & $\mathrm{Al} / \mathrm{Al}$ & 4 & 20 & $\begin{array}{c}7.4- \\
8.5\end{array}$ & $\begin{array}{c}92.01 \% \text { COD } \\
93.97 \% \text { turbidity } \\
49.78 \% \text { TDS }\end{array}$ & [39] \\
\hline Oily wastewater & $\mathrm{Al} / \mathrm{Al}$ & 8 & 20 & 3.6 & $\begin{array}{c}71 \% \text { oil and } \\
\text { grease } \\
14 \% \text { TDS } \\
71.3 \% \text { COD }\end{array}$ & [40] \\
\hline $\begin{array}{l}\text { Palm oil mil effluent } \\
\text { (POME) }\end{array}$ & $\mathrm{Al} / \mathrm{Al}$ & 40.21 & 45.67 & 4.4 & $\begin{array}{c}96.8 \% \text { color } \\
100 \% \text { TSS } \\
82.8 \% \text { COD }\end{array}$ & [41] \\
\hline $\begin{array}{l}\text { Mineral processing } \\
\text { wastewater }\end{array}$ & $\begin{array}{c}\text { Fe/Stainless } \\
\text { steel }\end{array}$ & 19.23 & 70 & 7.1 & $\begin{array}{l}\text { up to } 36.06 \% \\
\quad \text { galena } \\
\text { up to } 65.33 \% \\
\text { sphalerite }\end{array}$ & [24] \\
\hline
\end{tabular}

It is successfully used for decolorization of water, reduction of turbidity, water hardness, as well as for fluoride, phosphate, mercury, lead, chromium, nickel, copper, cobalt, boron, cadmium, iron, cesium, and strontium removal. It is also successfully used for the treatment of industrial wastewater from the pulp and paper industry, textile industry, food industry, etc. [29-32]. Table 3 gives a summary of related studies and applications of EC in the treatment of different wastewaters with different pollutants. The percentage of pollutants removal by the EC process is over $85 \%$ in most cases, so it is safe to say that this method is reliable as an alternative technology for wastewater treatment.

However, due to the large quantities and their complex nature, industrial wastewater treatment is a complex task. The EC process alone doesn't completely remove the COD, so the water can't be reused for industrial or domestic purposes. In order to improve the efficiency of pollutant removal, reduce electrolysis time and reduce the cost of the process, the EC process is often combined with other processes, such as ozonation, adsorption, filtration, biological and thermal treatments, Fenton 
process, etc. [20].

Asaithambi et al. [42] achieved an 85\% removal of COD by using the EC-peroxidation (ECP) process. They achieved a $13 \%$ increase in the removal of COD by adding hydrogen-peroxide (243 $\left.\mathrm{mg} \mathrm{l}^{-1}\right)$ with Fe electrodes and initial $\mathrm{pH}$ of 5. Bashir et al. [41] also achieved the reduction of the operating current density of $28.2 \%$ and the reduction of electrolysis time of $30 \%$ in the treatment of palm oil mill effluent by ECP (using Al electrodes at $\mathrm{pH}$ 4.4). However, the addition of strong oxidants, such as $\mathrm{H}_{2} \mathrm{O}_{2}$, makes the ECP process less environment-friendly.

Sharma et al. [43] investigated the efficiency of the electrocoagulation-electrooxidation (EC-EO) process. They concluded that EC-EO is a more promising method than ECF. It is more efficient in pollutant removal $(95 \%$ of organic pollutants removed) and utilizes less energy.

One of the most promising emerging hybrid technologies would be the electrocoagulation-membrane processes. These processes combine microfiltration membranes and nanofiltration membranes with electrocoagulation, thus standing out from advanced oxidational processes. This technology does not use harsh chemicals and does not produce unwanted by-products. On the other side, membrane fouling is a disadvantage, which could be overcome if the EC process is used as a pretreatment [44]. Changmai et al. [45] employed the EC-microfiltration process for the treatment of steel industry effluent and achieved a $100 \%$ removal of heavy metals (namely $\mathrm{Mn}$ ).

It should be noted that hybrid technologies could potentially replace conventional treatment technologies, but with more research undertaken. These technologies still need to be optimized and designed economically and efficiently.

\section{Conclusion}

$\mathrm{EC}$ is an electrochemical technique that has a wide range of applications and high efficiency of pollutant removal. It is often used for treating industrial wastewater and has been shown to have superior performance in the treatment of effluents containing suspended particles, oil, and grease, as well as pollutants of organic and inorganic nature. This technique has the potential to be applied in the treatment of industrial wastewaters, municipal wastewaters, as well as surface and groundwater with minimal equipment and short treatment time. To increase the efficiency of the EC process, it is usually used in combination with other wastewater treatment processes, but these hybrid technologies are still being developed. This process does not require the use of chemical reagents and the amount of sludge produced is less than the amount produced by chemical coagulation. However, this method has disadvantages related to the passivation of the anode as well as the deposition of sludge on the electrodes, thus inhibiting the continuity of the process. In addition, high concentrations of generated aluminum and iron ions can be released into the solution, which would have to be removed after the treatment. The efficiency of the EC process is influenced by several parameters, the most important ones being the $\mathrm{pH}$ of the treated solution and the operating current density. However, further studies of the influence of the geometry and shape of the electrodes on the efficiency of the EC process as well as the possible development of electrode materials that would increase the efficiency of pollutant removal are necessary

\section{Acknowledgements}

The authors would like to acknowledge financial support from the Ministry of Education, Science and Technological Development of the Republic of Serbia (Agreement No 451-03-9/2021-14/200124).

\section{References}

[1] E. Ali, Z. Yaakob, In Electrolysis, J. Kleperis Ed., InTech, London, 2012, p. 227.

[2] H. M. Guevara, S. Roy, In Wastewater Recycling and Management, S. K. Ghosh Ed., Springer, Singapore, 2019, p. 217.

[3] Y. Zhang, J. Mao, J. Zhao, B. Yang, Z. Zhang, Research on the Reuse Technology of Fracturing Flowback Fluids in Fracking, Energy Sources, Part A: Recovery, Utilization and Environmental Effects, 42(13) (2019) 1674-1680.

[4] P. K. Cornejo, Q. Zhang, J. R. Mihelcic, How Does Scale of Implementation Impact the Environmental Sustainability of Wastewater Treatment Integrated with Resource Recovery, Environmental Science \& Technology, 50 (2016) 6680-6689.

[5] M. Salgot, M. Folch, Wastewater Treatment and Water Reuse, Current Opinion on Environmental Science \& Health, 2 (2018) 64-74.

[6] G. Chen, Electrochemical technologies in wastewater treatment, Separation and Purification Technology, 38(1) (2004) 11-41.

[7] M. Y. A. Mollah, P. Morkovsky, J. A. G. Gomes, M. Kesmez, J. Parga, D. L. Cocke, Fundamentals, present and future perspectives of electrocoagulation, Journal of Hazardous Materials, 114(1-3) (2004) 199-210.

[8] S. R. Tchamango, O. Kamdoum, D. Donfack, D. Babale, Comparison of Electrocoagulation and Chemical Coagulation Processes in the Treatment of an Effluent of a Textile Factory, Journal of Applied Sciences and Environmental Management, 21(7) (2017) 1317-1322.

[9] Y. Feng, L. Yang, J. Liu, B. E. Logan, Electrochemical technologies for wastewater treatment and resource reclamation, Environmental Science: Water Research \& Technology, 2(5) (2016) 800-831.

[10] M. Bharath, B. M. Krishna, B. Manoj Kumar, A Review of Electrocoagulation Process for Wastewater treatment, International Journal of ChemTech Research, 11(3) (2018) 289-302.

[11] D. S. Babu, S. T. A Singh, V. P. Nidheesh, M. S. Kumar, Industrial wastewater treatment by electrocoagulation process, Separation Science and Technology, 55(17) (2020) 3195-3227.

[12] D. Ghernaout, B. Ghernaout, Sweep Flocculation as a Second Form of Charge Neutralisation - A review, 
Desalination and Water Treatment, 44 (2012) 15-28.

[13] C. An, G. Huang, Y. Yao, S. Zhao, Emerging Usage of Electrocoagulation Technology for Oil Removal from Wastewater: A Review, Science of Total Environment, 579 (2017) 537-556.

[14] Anantha Singh, T. S.; Ramesh, S. T. New Trends in Electrocoagulation for the Removal of Dyes from Wastewater: A Review, Environmental Engineering Science, 30 (2013) 333-349.

[15] Bassyouni, D. G.; Hamad, H. A.; El-Ashtoukhy, E.-S. Z.; Amin, N. K.; El-Latif, M. M. A. Comparative Performance of Anodic Oxidation and Electrocoagulation as Clean Processes for Electrocatalytic Degradation of Diazo Dye Acid Brown 14 in Aqueous Medium, Journal of Hazardous Materials, 335 (2017) 178-187.

[16] Nandi, B. K.; Patel, S. Effects of Operational Parameters on the Removal of Brilliant Green Dye from Aqueous Solutions by Electrocoagulation, Arabian Journal of Chemistry, 10 (2017) 2961-2968.

[17] V. Khandegar, A. K. Saroha, Electrocoagulation for the treatment of textile industry effluent - A review, Journal of Environmental Management, 128 (2013) 949-963.

[18] O. M. Hafez, M. A. Shoeib, M. A. El-Khateeb, H. I. AbdelShafy, A. O. Youssef, Removal of scale forming species from cooling tower blowdown water by electrocoagulation using different electrodes, Chemical Engineering Research and Design, 136 (2018) 347-357.

[19] K. Thella, B. Verma, V. C. Srivastava, K. K. Srivastava, Electrocoagulation study for the removal of arsenic and chromium from aqueous solution, Journal of Environmental Science and Health, Part A: Toxic/Hazardous Substances and Environmental Engineering, 43(5) (2008) 554-562.

[20] I. Linares-Hernández, C. Barrera-Díaz, G. Roa-Morales, B. Bilyeu, F. Ureña-Núñez, Influence of the anodic material on electrocoagulation performance, Chemical Engineering Journal, 148(1) (2009) 97-105.

[21] Y. Demirici, L. C. Pekel, M. Alpbaz, Investigation of Different Electrode Connections in Electrocoagulation of Textile Wastewater Treatment, International Journal of Electrochemical Science, 10 (2015) 2685-2693.

[22] M. F. Eskibalci, M. F. Ozkan, An investigation of the effect of $\mathrm{NaCl}$ concentration on the electrocoagulation of $\mathrm{co}$ al preparation plant tailings, Physicochemical Problems of Mineral Processing, 54(3) (2018) 934-943.

[23] E. A. Vik, D. A. Carlson, A. S. Eikum, E. T. Gjessing, Electrocoagulation of portable water, Water Resources Research, 18 (1984) 1355-1360.

[24] G. Jing, S. Ren, Y. Gao, W. Sun, Z. Gao, Electrocoagulation: A Promising Method to Treat and Reuse Mineral Processing Wastewater with High COD, Water, 12(2) (2020) 595-607.

[25] S. M. Didar- UI Islam, Electrocoagulation (EC) technology for wastewater treatment and pollutants removal, Sustainable Water Resources Management, 5(3) (2017) 359-380.

[26] F. Shen, P. Gao, X. Chen, G. Chen, Electrochemical removal of fluoride ions from industrial wastewater, Chemical Engineering Science, 58 (2003) 987-993.

[27] K. Scott, Electrochemical Processes for Clean Technology, The Royal Society of Chemistry, Cambridge, 1995.

[28] X. Chen, G. Chen, P. L. Yue, Modeling the electrolysis voltage of electrocoagulation process using aluminum electrodes, Chemical Engineering Science, 57(13) (2002) 2449-2455.
[29] I. Kabdaşlı, I. Arslan-Alaton, T. Ölmez-Hancı, O. Tünay, ElectrocoagulationApplications for Industrial Wastewaters: A Critical Review, Environmental Technology Reviews, 1 (2012) 2-45.

[30] T. Karichappan, S. Venkatachalam, P. M. Jeganathan, K. Sengodan, Treatment of Rice Mill Wastewater Using Continuous Electrocoagulation Technique: Optimization and Modelling, Journal of the Korean Chemical Society, 57 (2013) 761-768.

[31] Y. Yavuz, B. Ögütveren, Treatment of Industrial Estate Wastewater by the Application of Electrocoagulation Process Using Iron Electrodes, Journal of Environmental Management, 207 (2018) 151-158.

[32] P. Krystynik, P. Masin, Z. Krusinova, P. Kluson, Application of Electrocoagulation for Removal of Toxic Metals from Industrial Effluents, International Journal of Environmental Science and Technology, 16 (2019) 4167-4172.

[33] S. Kongjao, S. Damronglerd and M. Hunsom, Simultaneous Removal of Organic and Inorganic Pollutants in Tannery Wastewater Using Electrocoagulation Technique, Korean Journal of Chemical Engineering, 25(4) (2008) 703-709.

[34] A. Dimoglo, P. Sevim-Elibol, Dinç, K. Gökmen, H. Erdoğan, Electrocoagulation/electroflotation as a combined process for the laundry wastewater purification and reuse, Journal of Water Process Engineering, 31 (2019), 100877.

[35] S. Bener, Ö. Bulca, B. Palas, G. Tekin, S. Atalay, G. Ersöz, Electrocoagulation process for the treatment of real textile wastewater: Effect of operative conditions on the organic carbon removal and kinetic study, Process Safety and Environmental Protection, 129 (2019) 47-54.

[36] M. Wu, Y. Hu, R. Liu, S. Lin, W. Sun, H. Lu, Electrocoagulation method for treatment and reuse of sulphide mineral processing wastewater: characterization and kinetics, Science of the Total Environment, 696 (2019) 134063.

[37] M. Zaied, N. Bellakhal, Electrocoagulation Treatment of Black Liquor from Paper Industry, Journal of Hazardous Materials, 163(2-3) (2009) 995-1000.

[38] F. Akbal, S. Camcı, Copper, Chromium and Nickel Removal from Metal Plating Wastewater by Electrocoagulation, Desalination, 269(1-3) (2011) 214-222.

[39] C.J. Nawarkar, V.D. Salkar, Solar powered Electrocoagulation system for municipal wastewater treatment, Fuel, 237 (2019) 222-226.

[40] M. Changmai, M. Pasawan, M.K. Purkait, Treatment of oily wastewater from drilling site using electrocoagulation followed by microfiltration, Separation and Purification Technology, 210 (2019) 463-472.

[41] M.J. Bashir, J.H. Lim, S.S. Abu Amr, L.P. Wong, Y.L. Sim, Post treatment of palm oil mill effluent using electrocoagulation-peroxidation (ECP) technique, Journal of Cleaner Production, 208 (2019) 716-727.

[42] P. Asaithambi, B. Sajjadi, A.R. Abdul Aziz, W.M.A. Bin Wan Daud, Performance evaluation of hybrid electrocoagulation process parameters for the treatment of distillery industrial effluent, Process Safety and Environmental Protection, 104 (2016) 406-412.

[43] S. Sharma, A. Aygun, H. Simsek, Electrochemical treatment of sunflower oil refinery wastewater and optimization of the parameters using response surface methodology, Chemosphere, 249 (2020) 126511.

[44] S. Chellam, M.A. Sari, Aluminum electrocoagulation as pretreatment during microfiltration of surface water containing NOM: a review of fouling, NOM, DBP, and 
virus control, Journal of Hazardous Materials, 304 (2016) 490-501.

[45] M. Changmai, P. P. Das, P. Mondal, M. Pasawan, A. Sinha, P. Biswas, S. Sarkar \& M. K. Purkait, Hybrid electrocoagulation-microfiltration technique for treatment of nanofiltration rejected steel industry effluent, International Journal of Environmental Analytical Chemistry, (2020) 1-22.

\section{PREGLED MEHANIZMA PROCESA ELEKTROKOAGULACIJE I NJEGOVA PRIMENA ZA PREČIŠĆAVANJE OTPADNIH VODA}

Tijana Jovanović, Nena Velinov, Milica Petrović, Slobodan Najdanović, Danijela Bojić, Miljana Radović,

Univerzitet u Nišu, Prirodno-matematički fakultet, Departman za hemiju, Srbija

Prečišćavanje otpadnih voda, posebno industrijskog porekla, predstavlja veliki izazov. lako su već ustanovljene metode za prečišćavanje otpadnih voda, aktivno se radi na razvoju efikasnijih i ekonomičnijih metoda. Poslednjih godina je velika pažnja usmerena ka elektrohemijskim postupcima, od kojih se najviše pažnje usmerava ka elektrokoagulaciji. U ovom radu dat je detaljan opis mehanizma procesa elektrokoagulacije, kao i primene ove metode u prečišćavanju otpadnih voda različitog porekla.
(PREGLEDNI RAD)

UDK 66.087.5:628.387

DOI 10.5937/savteh2101063J

Ključne reči: efluenti; elektrohemijski postupci prečišćavanja vode; elektrokoagulacija; otpadne vode; polutanti; prečišćavanje vode 